\title{
Role of Solar Water Heating in Multifamily Zero Energy Homes
}

Robb Aldrich and James Williamson Consortium for Advanced Residential Buildings 


\section{NOTICE}

This report was prepared as an account of work sponsored by an agency of the United States government. Neither the United States government nor any agency thereof, nor any of their employees, subcontractors, or affiliated partners makes any warranty, express or implied, or assumes any legal liability or responsibility for the accuracy, completeness, or usefulness of any information, apparatus, product, or process disclosed, or represents that its use would not infringe privately owned rights. Reference herein to any specific commercial product, process, or service by trade name, trademark, manufacturer, or otherwise does not necessarily constitute or imply its endorsement, recommendation, or favoring by the United States government or any agency thereof. The views and opinions of authors expressed herein do not necessarily state or reflect those of the United States government or any agency thereof.

Available electronically at SciTech Connect http:/www.osti.gov/scitech

Available for a processing fee to U.S. Department of Energy and its contractors, in paper, from:

U.S. Department of Energy

Office of Scientific and Technical Information

P.O. Box 62

Oak Ridge, TN 37831-0062

OSTI http://www.osti.gov

Phone: 865.576 .8401

Fax: 865.576.5728

Email: reports@osti.gov

Available for sale to the public, in paper, from:

U.S. Department of Commerce

National Technical Information Service

5301 Shawnee Road

Alexandria, VA 22312

NTIS http://www.ntis.gov

Phone: 800.553 .6847 or 703.605 .6000

Fax: 703.605.6900

Email: orders@ntis.gov 


\title{
Role of Solar Water Heating in Multifamily Zero Energy Homes
}

\author{
Prepared for: \\ The National Renewable Energy Laboratory \\ On behalf of the U.S. Department of Energy's Building America Program \\ Office of Energy Efficiency and Renewable Energy \\ 15013 Denver West Parkway \\ Golden, CO 80401 \\ NREL Contract No. DE-AC36-08GO28308 \\ Prepared by: \\ Robb Aldrich and James Williamson \\ Consortium for Advanced Residential Buildings \\ Steven Winter Associates, Inc. \\ 61 Washington St. \\ Norwalk, CT 06854 \\ NREL Technical Monitor: Stacey Rothgeb \\ Prepared under Subcontract No. KNDJ-0-40342-05
}

April 2016 
The work presented in this report does not represent performance of any product relative to regulated minimum efficiency requirements.

The laboratory and/or field sites used for this work are not certified rating test facilities. The conditions and methods under which products were characterized for this work differ from standard rating conditions, as described.

Because the methods and conditions differ, the reported results are not comparable to rated product performance and should only be used to estimate performance under the measured conditions. 


\section{Contents}

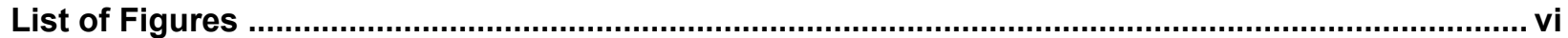

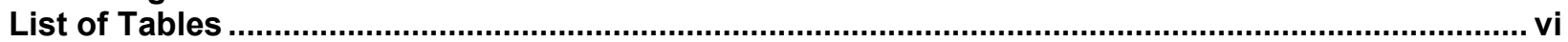

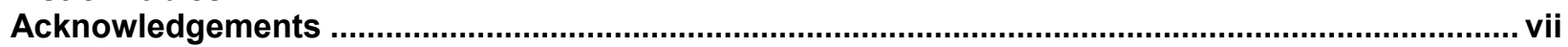

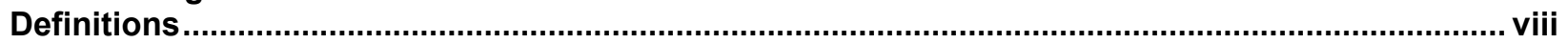

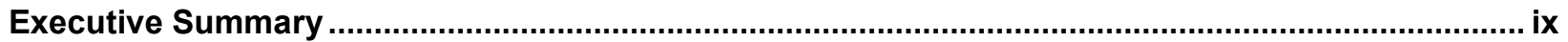

1 Introduction

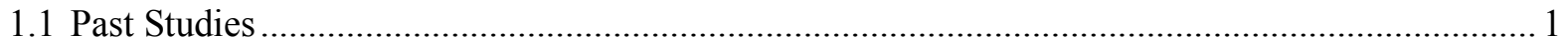

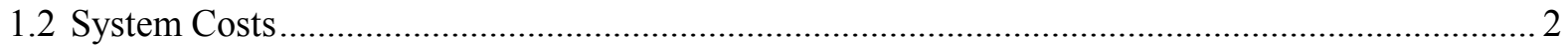

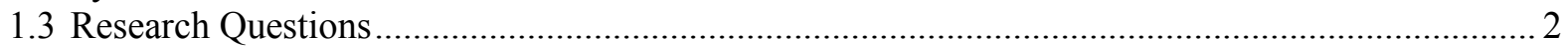

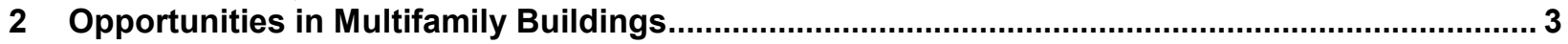

2.1 Scale 3

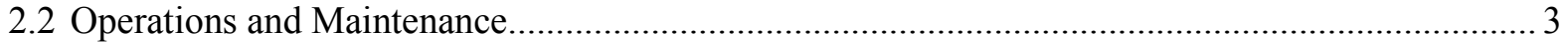

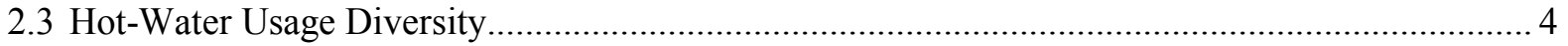

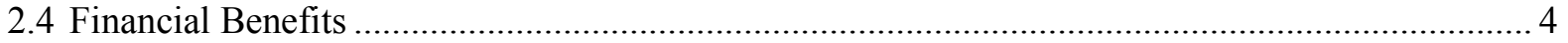

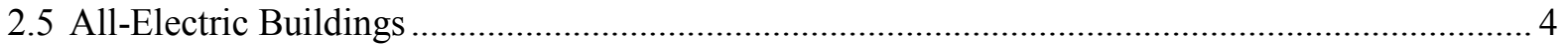

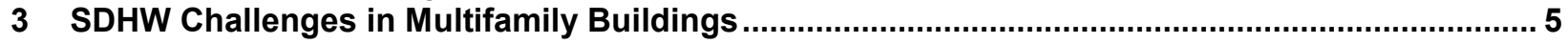

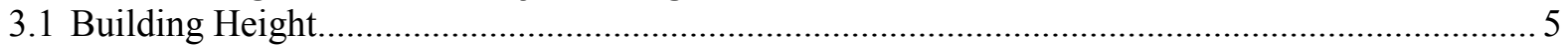

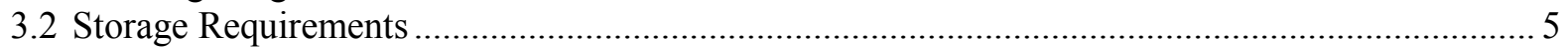

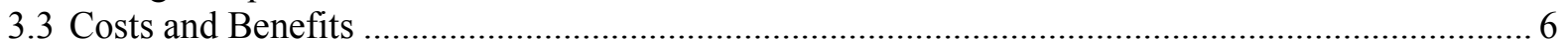

3.4 Commissioning, Monitoring, Reliability, and Performance …..................................................... 6

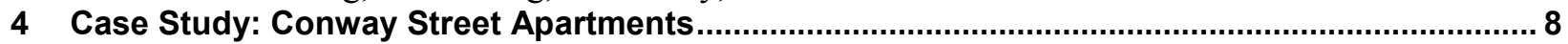

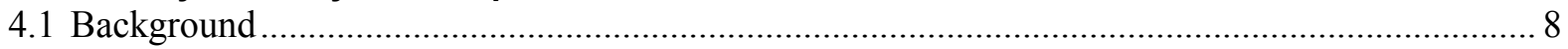

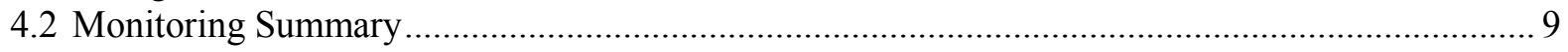

4.3 Operations and Maintenance

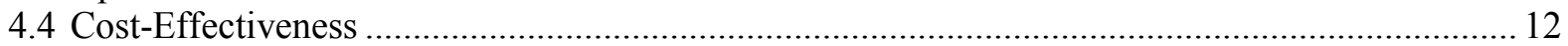

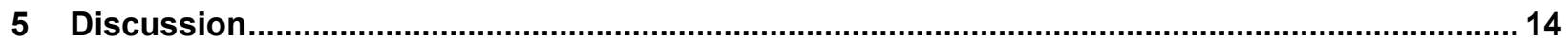

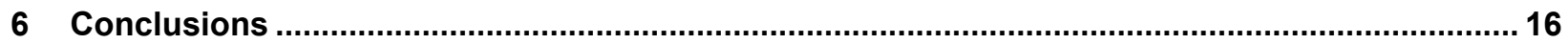

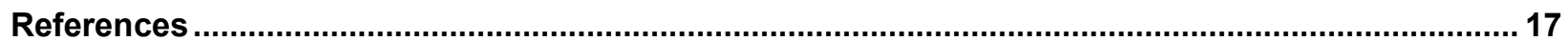




\section{List of Figures}

Figure 1. This 1,500-gallon solar storage tank served to preheat water for 59 apartments.

Figure 2. The $960 \mathrm{ft}^{2}$ of solar collectors occupy most of the available, unshaded roof area on this six-story multifamily building.

Figure 3. Evacuated-tube solar collectors mounted as awnings over south-facing windows .......... 8

Figure 4. Simple schematic of Conway Street hot-water systems. Each of the three storage tanks holds 110 gal. (HX=heat exchanger, AFUE=annual fuel utilization efficiency).

Figure 5. Schematic of sensor locations on the boiler and solar loops. $T$ indicates temperature sensor; $F$ indicates flow meter.

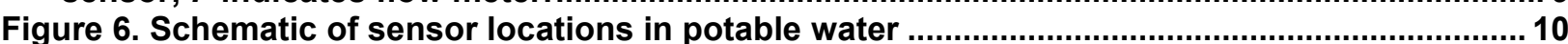

Figure 7. Daily average heat delivered for domestic hot water.................................................... 11

Unless otherwise indicated, all figures were created by $C A R B$.

\section{List of Tables}

Table 1. Example Costs for SDHW System Before Incentives ........................................................ 6

Table 2. Annual per-Unit Fuel Savings for SDHW Example......................................................... 6

Table 3. Summary of Approximate Solar-Thermal Costs and Incentives ........................................ 12

Table 4. Example Solar Savings with Other Water-Heating Fuels. Conway Street Loads and Costs

Are Used.

Unless otherwise indicated, all tables were created by CARB. 


\section{Acknowledgements}

The Consortium for Advanced Residential Buildings would like to thank Olive Street Development and Zaccheo Properties for their participation in the evaluation of the Conway Street apartments. Thanks also to the National Renewable Energy Laboratory and Davis Energy Group for providing resources and support. This work was funded through the Building America Program, part of the U.S. Department of Energy Building Technologies Office. 


\section{Definitions}

CARB Consortium for Advanced Residential Buildings

CSI California Solar Initiative

DHW Domestic hot water

DOE U.S. Department of Energy

EIA Energy Information Administration

HVAC Heating, ventilating, and air conditioning

MACRS Modified accelerated cost-recovery system

NREL National Renewable Energy Laboratory

O\&M Operations and maintenance

PV Photovoltaic (solar electric)

SDHW Solar domestic hot water 


\section{Executive Summary}

Solar domestic hot-water (SDHW) systems have been installed on buildings for decades, but because of relatively high costs they have not achieved significant market penetration in most of the country. However, as more buildings move toward zero net energy consumption, many designers and developers are looking more closely at SDHW. In multifamily buildings especially, SDHW may be more practical for several reasons:

- When designing for zero net energy consumption, solar water heating may be part of the lowest-cost approach to meet water-heating loads.

- Because of better scale, SDHW systems in multifamily buildings cost significantly less per dwelling than in single-family homes.

- Many low-load buildings are moving away from fossil fuels entirely. SDHW savings are substantially greater when displacing electric-resistance water heating.

- In addition to federal tax incentives, some states have substantial financial incentives that dramatically reduce the costs (or increase the benefits) of SDHW systems in multifamily buildings.

With support from the U.S. Department of Energy Building America Program, the Consortium for Advanced Residential Buildings (CARB) worked with a developer in western Massachusetts to evaluate a SDHW system on a 12-unit apartment building. Olive Street Development completed construction in the spring of 2014, and CARB has been monitoring the performance of the water-heating systems since May 2014.

The SDHW system consists of $372 \mathrm{ft}^{2}$ of evacuated-tube collectors with 330 gallons of storage. During the first 12 months that the building was occupied, the solar-thermal system offset approximately 450 therms of natural gas (saving $\$ 630$ at average gas rates of $\$ 1.40 /$ therm). Total installed cost of the SDHW system was $\$ 31,000$, but federal tax incentives and a state solar incentive lowered costs to near $\$ 9,000$. The SDHW system also helped the developer achieve the highest level of incentives in a utility-sponsored energy-efficiency program; this resulted in additional rebates of $\$ 24,000$.

When trying to compare this system's performance to the performance of systems in similar studies, CARB found very few published evaluations of SDHW systems in multifamily buildings. CARB believes that such evaluations could be of great use to developers, building owners, and system designers in making better decisions about selecting SDHW systems in zero energy buildings. 


\section{Introduction}

In 2009, the most recent year for which data are available from the Energy Information Administration (EIA 2011), 2 million square feet of solar water-heating collectors were sold in the United States. This was about seven times higher than 2001 shipments but five times lower than 1984 shipments. Solar water heating has had a checkered history.

The Consortium for Advanced Residential Buildings (CARB), with support from the U.S. Department of Energy (DOE) Building America Program, has worked with builders across the country to assess the most practical, cost-effective means to reduce home energy consumption and approach zero energy. CARB, along with other Building America teams, has evaluated solar water-heating systems in numerous homes. Many of these projects have found that solar systems are not designed properly, installed correctly, commissioned, or maintained properly (CARB 2010, Rittlemann 2004). Even when working properly, when these systems are offsetting operating costs of efficient natural gas water heaters, the natural gas savings alone often do not justify the cost of the solar thermal system (Aldrich 2006).

Cost, of course, is not the only important factor. Solar thermal systems can certainly offset fossilfuel use. When offsetting electric-resistance water heating, cost savings and environmental benefits are more significant. In most single-family homes in colder climates, however, CARB has found that active solar thermal is not part of the most practical, lowest-cost approach to zero net energy (Aldrich 2014).

In multifamily applications, CARB has seen much more promise for solar water heating. Nationwide market-penetration data for solar water-heating systems in multifamily buildings could not be found, but a study in California showed that $0.8 \%$ of apartments (with five or more units/building) had solar water heating in 2009 (CA Utilities 2011). Although this is certainly a small percentage, it represents nearly 17,000 dwelling units. The growing number of systems in California is due in part to solar thermal being a prescriptive requirement in the 2013 Title 24 energy code for low-rise multifamily buildings. There are also financial incentives available through the California Solar Initiative (CSI) (CEC 2012). Between May 2010 and July 2015, about 2,400 systems were installed on multifamily buildings under the CSI program.

\subsection{Past Studies}

Despite the substantial number of systems installed, there is an apparent shortage of published performance data from multifamily solar domestic hot-water (SDHW) systems. One study of seven multifamily solar systems in the San Diego area (Itron 2011) compared monitored performance to FChart and TRNSYS modeling predictions. Monitored performance results were generally in line with predictions except for several instances when hot-water consumption was dramatically lower than expected.

In the San Francisco Bay area, Davis Energy Group monitored summertime performance of solar thermal systems on two buildings, each with about 50 units, $480 \mathrm{ft}^{2}$ of flat-plate collectors, and 720 gallons of storage (Springer 2014). During the summer period monitored, solar fractions were $34 \%$ and $71 \%$ in the two buildings, but an innovative control system to reduce recirculation losses increased solar fractions to $51 \%$ and $81 \%$, respectively. During the course of a year, this 
control strategy was expected to increase solar fraction from approximately $25 \%$ to $39 \%$ in similar applications.

A separate study of five multifamily buildings in the Bay area from the 1990s showed that savings from solar-thermal systems were modest and - in many buildings — did not persist during the five years evaluated (Ritschard 1992).

\subsection{System Costs}

Even before incentives or subsidies, costs of solar water-heating systems vary with location, application, and configuration, but some rules of thumb may still be helpful when contemplating the role of solar water heating. An examination of multifamily SDHW system costs in California initially found that many stakeholders use the rule of thumb of $\$ 150 / \mathrm{ft}^{2}$ (CA Utilities 2011). A closer examination from the same study, however, showed that costs followed the trends below:

$$
\begin{aligned}
& \text { Installed cost of small systems }\left(<800 \mathrm{ft}^{2}\right)=\$ 112 / \mathrm{ft}^{2}+\$ 1,428 \\
& \text { Installed cost of large systems }\left(>800 \mathrm{ft}^{2}\right)=\$ 107 / \mathrm{ft}^{2}+2,689
\end{aligned}
$$

An examination of a California database for solar incentives (CSI-Thermal 2015) shows an average cost of $\$ 104 / \mathrm{ft}^{2}$ (both for multifamily and commercial systems). A much smaller database (only 11 systems) of systems installed as part of a rebate program in Massachusetts shows that average installed costs are $\$ 155 / \mathrm{ft}^{2}$ in multifamily buildings of five or more units. The higher Massachusetts numbers may be a result of a less mature market, but these prices may be falling in Massachusetts. The system in the case study described below (on a 12-unit building in Massachusetts) cost less than $\$ 100 / \mathrm{ft}^{2}$. This system and many others are not yet included in the online database. A review of all of these sources shows that installed costs for solar-thermal systems on multifamily buildings are typically in the range of $\$ 90 / \mathrm{ft}^{2}-\$ 160 / \mathrm{ft}^{2}$ of collector area.

\subsection{Research Questions}

This report examines the opportunities, benefits, and challenges of using solar water heating to help multifamily buildings approach zero net energy consumption. Specifically, this report seeks to answer the following questions:

- How do the costs and benefits of multifamily SDHW systems compare to smaller singlefamily systems?

- Can SDHW systems be cost-effective in multifamily buildings? If so, in what types of buildings or applications?

The authors have investigated the literature and used experience with multifamily developers in the Northeast to try to answer these questions. CARB has also monitored performance of a SDHW system recently installed on a 12-unit building in Massachusetts. In addition to performance data, the authors were able to obtain fairly detailed information on costs and incentives. This system serves as a case study to examine cost and performance criteria that may make SDHW practical and viable. This document does not serve as an introduction to the types and operation of solar water-heating systems, but several good resources are available for this purpose (including DOE 2013, Mehalic 2010, Baechler 2007). 


\section{Opportunities in Multifamily Buildings}

\subsection{Scale}

The key advantage for solar thermal in multifamily buildings (when compared to single-family buildings) is scale. An evaluation project in San Diego found that commercial and multifamily solar-thermal systems cost $28 \%$ less per unit of collector area than single-family solar systems (Itron 2011). Although hard costs for collectors scale fairly linearly with system size, balance-ofsystem components (e.g., piping, valves, pumps, controls) and labor do not scale linearly. Although larger thermal storage vessels cost more than smaller vessels, here again there are opportunities for savings from scale. The 1,500-gallon storage tank in Figure 1, for example, preheats water for 59 apartments in Brooklyn, NY. Upfront cost for this large tank was comparable to the cost of eight pressurized, 100-gallon tanks (typical in many single-family solar systems).

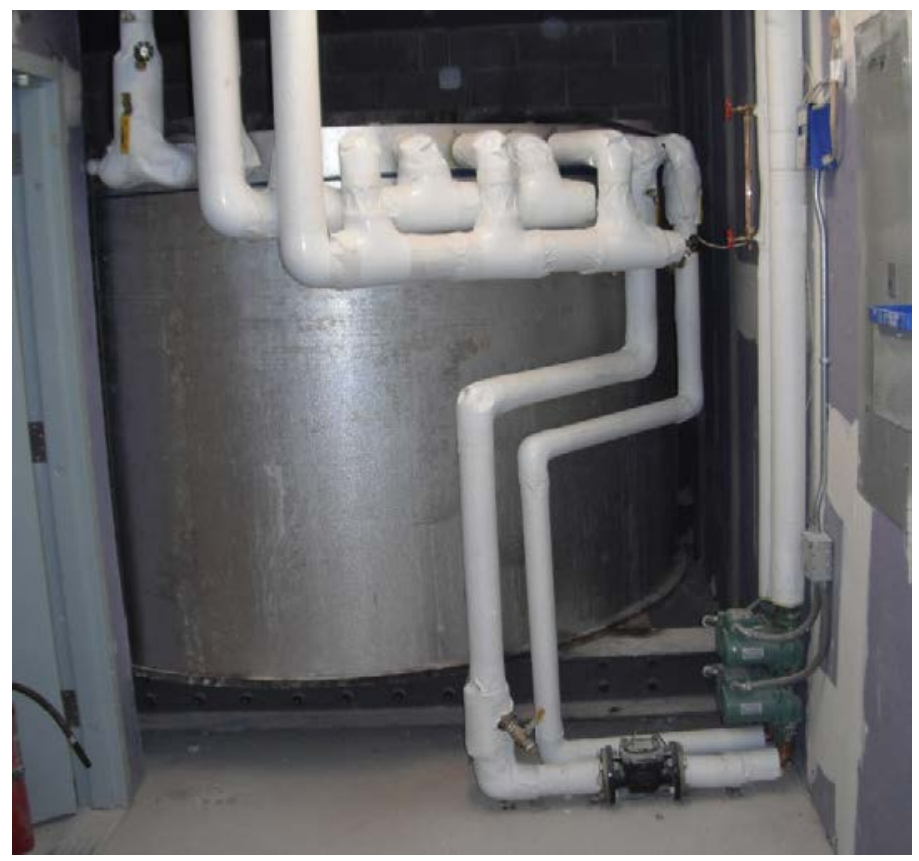

Figure 1. This 1,500-gallon solar storage tank served to preheat water for 59 apartments.

\subsection{Operations and Maintenance}

Like any mechanical system with moving parts and relatively high temperatures, solar-thermal systems require periodic maintenance. The type and frequency of maintenance needed varies tremendously. Some contractors recommend yearly inspections or tune-ups; other systems operate for years virtually untouched. When systems do require frequent maintenance, these costs can quickly eat into energy savings. Average annual water-heating cost in U.S. homes was $\$ 280$ in 2009 (EIA 2009), and solar-thermal systems typically offset $50 \%-80 \%$ of these costs. In a single-family home, a service visit could negate a year's solar savings.

In multifamily buildings, scale again can offer advantages with respect to operations and maintenance $(\mathrm{O} \& \mathrm{M})$ costs. An annual service visit might have a similar cost but represent a 
much smaller fraction of solar savings. In other instances, building-maintenance staff may be able to perform routine system checks and maintenance without the need for outside contractors. Unfortunately, actual O\&M costs for multifamily solar-thermal systems are not well documented. None of the literature that CARB found lists actual or expected maintenance costs, and CARB has not obtained reliable estimates from solar contractors.

\subsection{Hot-Water Usage Diversity}

In single-family homes, solar-thermal systems are typically sized to provide $50 \%-80 \%$ of waterheating loads. In the summer, these systems often collect more energy than is used in a home, especially when occupants travel or are inconsistent in their water use. Because of the diversity in multifamily buildings, there is a very consistent water-heating load. Occupants may be away just as much, but they are not all away at the same time. This consistent load means that there is much less potential for available solar energy to go unused.

\subsection{Financial Benefits}

In addition to the cost and scale advantages described above, owners of multifamily buildings may be eligible to take advantage of accelerated depreciation (modified accelerated costrecovery system, MACRS). When appropriate, MACRS allows owners to deduct the upfront cost of the solar system at an accelerated schedule over the first six years of ownership (SEIA 2015).

\subsection{All-Electric Buildings}

In high-performance multifamily buildings, inverter-driven air-source heat pumps (ASHPs) are being used with increasing frequency. These heat pumps can easily meet the small loads of these apartments fairly efficiently (even in colder climates). With space-heating loads met with electricity, many developers are moving away from fossil fuels entirely. By avoiding natural gas, developers can reduce initial infrastructure costs and ongoing utility service charges, but providing hot water with electric resistance can be quite expensive. Especially in buildings targeting zero net energy, some developers are finding that solar water heating is an excellent solution to minimizing upfront infrastructure costs and ongoing operating costs. 


\section{SDHW Challenges in Multifamily Buildings}

\subsection{Building Height}

Market assessments in California have shown that typical sizes for solar-thermal arrays are 0.1$1.0 \mathrm{ft}^{2}$ per daily gallon of hot water consumed (CA Utilities 2011). If average hot-water consumption is $30 \mathrm{gal} / \mathrm{d}$ per unit, this translates to $3-30 \mathrm{ft}^{2}$ of collector per unit. For many lowrise buildings with flat roofs, adequate roof area for collectors is not a major limitation. However, as buildings get taller, the ratio of available roof area to desired collector area can drop very quickly.

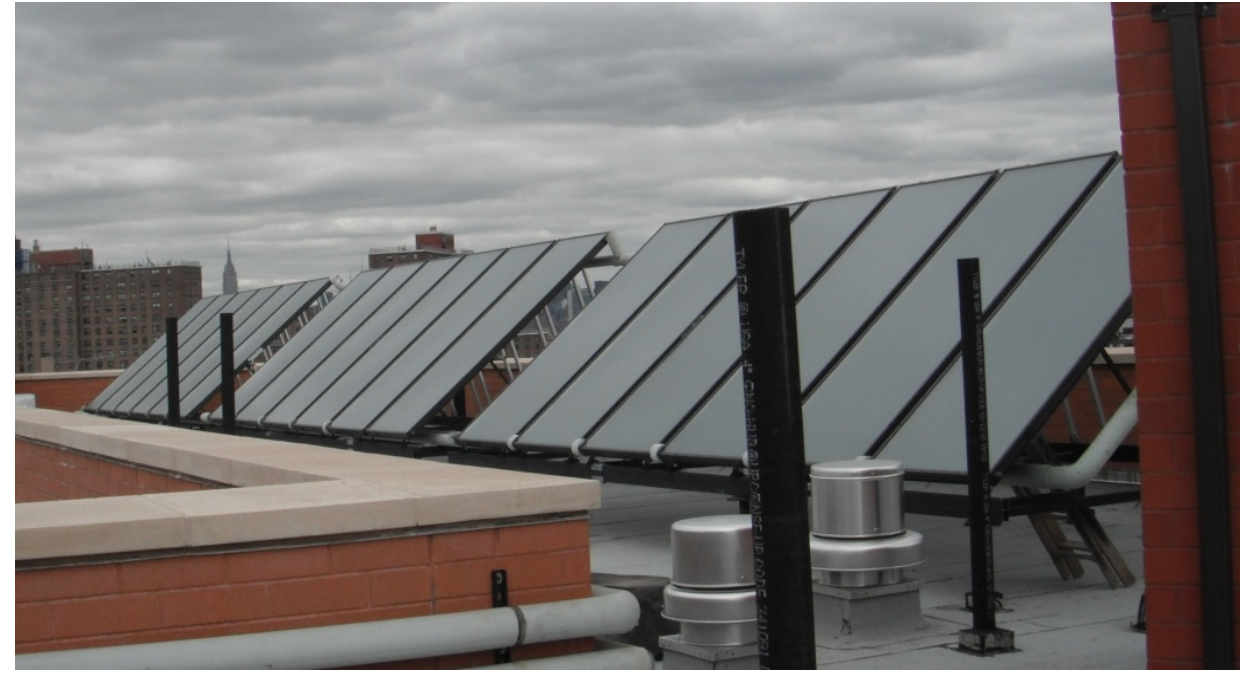

Figure 2. The $960 \mathrm{ft}^{2}$ of solar collectors occupy most of the available, unshaded roof area on this six-story multifamily building.

For taller buildings with basement mechanical rooms (and thermal storage), piping runs can also be more problematic. The 1,500-gallon storage tank in Figure 1 was located on the top floor of a new, eight-story building (along with boilers and auxiliary water heaters), but there were additional structural requirements. With longer piping runs, piping cost, pumping energy, and heat loss from this piping, the building height can complicate solar installations.

Although there is no hard-and-fast rule for which building heights are appropriate for solar water heating, CARB has seen more potential for practical systems in buildings up to eight stories.

\subsection{Storage Requirements}

Space is at a premium in many buildings, and solar-thermal systems require substantial thermalstorage volumes. Although multifamily applications often allow for advantageous scale in storage costs (as discussed above), the space needed for this storage can still be prohibitive. In CARB's experience, multifamily SDHW systems have storage capacities of about $1-1.5 \mathrm{gal} / \mathrm{ft}^{2}$ of collector area. This ratio can certainly vary substantially. In larger buildings with relatively small solar-thermal systems, for example, a large and diverse DHW load may reduce the need for large storage (e.g., if solar heat is used nearly as quickly as it is collected, there is no need for large volumes to store heat for longer periods of time). Still, CARB finds the $1-1.5 \mathrm{gal} / \mathrm{ft}^{2} \mathrm{rule}$ of thumb useful for some preliminary solar assessments. The space and weight of these storage 
tanks can be prohibitive in some buildings. In others, this constraint can limit the size of the solar-thermal system.

\subsection{Costs and Benefits}

Although multifamily building scale can offer cost advantages compared to single-family applications, solar domestic water heating is still often not cost-effective by many metrics. Using common costs and sizes outlined above, a simple cost example is outlined in Table 1.

Table 1. Example Costs for SDHW System Before Incentives

\begin{tabular}{|c|c|}
\hline DHW Consumption & $30 \mathrm{gal} / \mathrm{unit}$ per day \\
\hline Collector Area & $20 \mathrm{ft}^{2} / \mathrm{unit}^{2}$ \\
\hline Solar System Cost & $\$ 120 / \mathrm{ft}^{2}$ \\
\hline Solar Cost per Unit & $\$ 2,400 /$ unit \\
\hline
\end{tabular}

Using RETScreen to model this simple example, CARB modeled 1,000 $\mathrm{ft}^{2}$ of flat-plate collectors on a 50-unit building in Washington, DC. The model showed that the solar-thermal system would contribute 3,100 kBtu/y per unit to water-heating loads. Fuel and cost savings - using national average residential energy rates (EIA 2015a) and an auxiliary water-heating efficiency of $85 \%$ - are outlined in Table 2.

Table 2. Annual per-Unit Fuel Savings for SDHW Example

\begin{tabular}{cc|c|c}
\cline { 2 - 4 } & Gas [therms] & Oil [gal] & Electricity [kWh] \\
\hline Solar Fuel Savings & 36 & 26 & 1,061 \\
Rate [per Fuel Unit] & $\$ 1.00$ & $\$ 2.93$ & $\$ 0.121$ \\
Cost Savings & $\$ 36$ & $\$ 76$ & $\$ 128$ \\
\hline
\end{tabular}

The savings shown in Table 2 alone do not present a compelling justification of the costs in Table 1 . There are many other factors, however, that can come into play in this very simplified example. These factors include:

- $30 \%$ federal corporate tax credit

- MACRS allowing accelerated depreciation deductions

- State and utility incentives for solar-thermal systems (dsireusa.org)

- State and utility building-performance incentives (to which solar thermal can contribute substantially).

In multifamily projects where developers are striving for zero net energy, CARB has found that SDHW systems can be practical. In the case study described below, the developer was able to take advantage of all of these additional incentives to make SDHW a very attractive solutioneven when displacing relatively inexpensive natural gas.

\subsection{Commissioning, Monitoring, Reliability, and Performance}

From talking with many building owners, designers, and contractors about SDHW systems, it is clear that there are many strong opinions both for and against them. Some building owners have had repeated problems with SDHW systems and claim they will never use them again; others 
swear by solar-thermal systems' performance and reliability. Unfortunately, anecdotal evidence of solar performance (or lack of performance) seems to be the most abundant type of evidence. CARB is aware of several evaluation projects under way, but published studies or evaluation findings are rare. As with most building systems, solar systems work best when carefully designed, installed, and commissioned. CARB also strongly recommends that monitoring systems be installed so that performance can be evaluated (and problems identified) over time. 


\section{Case Study: Conway Street Apartments}

\subsection{Background}

In Greenfield, Massachusetts, Olive Street Development transformed an old elementary school building into twelve rental apartments. Most of the water-heating energy at the Conway Street apartments is provided by a solar-thermal system consisting of $372 \mathrm{ft}^{2}$ of evacuated-tube collectors (eight Thermopower VHP25 panels) coupled with three, 110-gallon storage tanks. Because the building's hip roofs and dormers do not allow for significant south-facing collector area on the roof, collectors are mounted as awnings over several of the large, south-facing windows (see Figure 3). These four collector awnings are connected in parallel. A 40\% propylene glycol solution runs between the collectors and heat exchangers in the storage tanks. When glycol is not flowing, it drains into a drain-back tank located in the basement mechanical room.

Each of the three storage tanks contains two heat exchangers. The glycol solution heated by the solar system runs through the lower heat exchangers; boiler water runs through the upper heat exchangers (see Figure 4). All heat exchangers are run in parallel (reverse return).

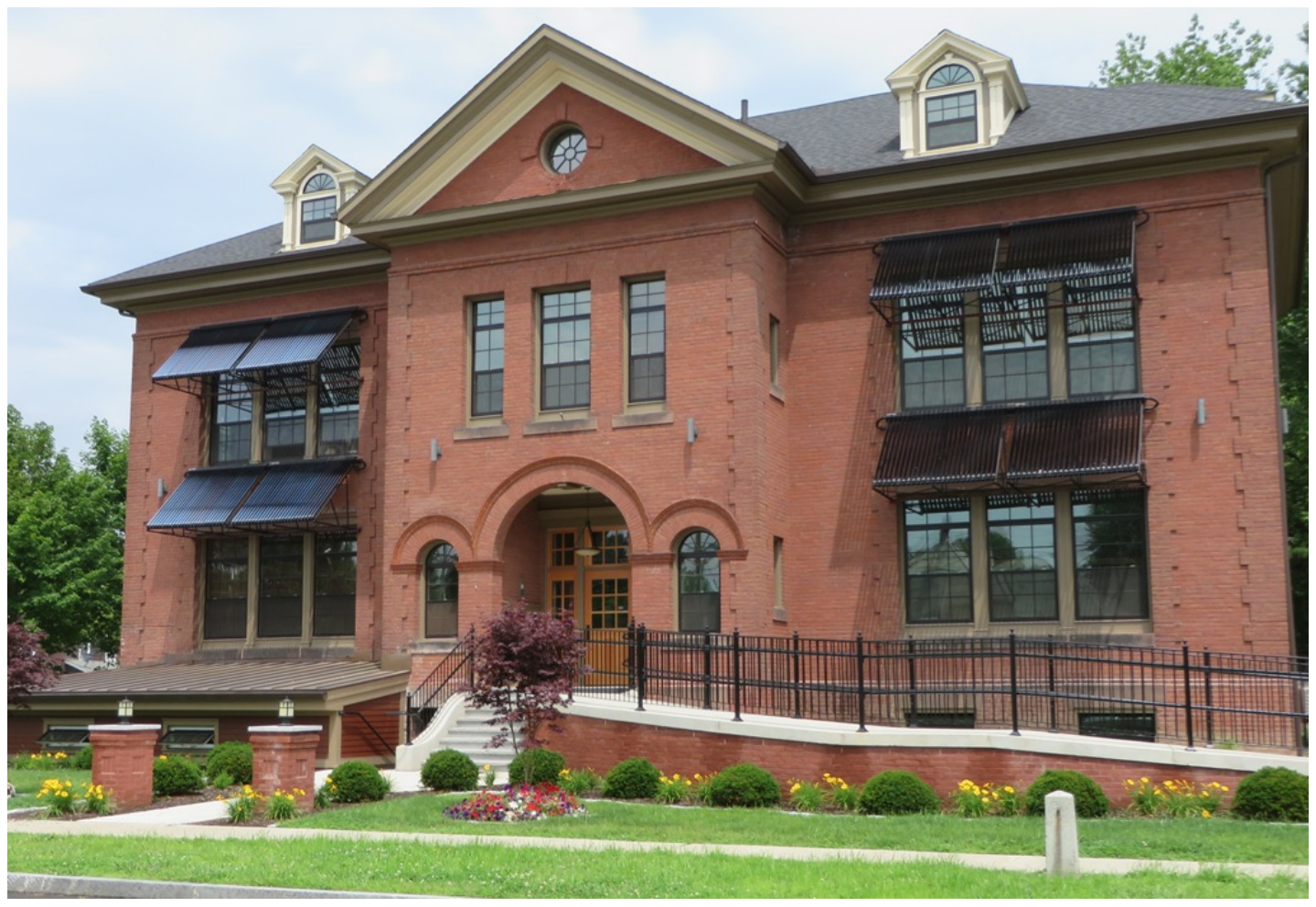

Figure 3. Evacuated-tube solar collectors mounted as awnings over south-facing windows 
Figure 4. Simple schematic of Conway Street hot-water systems. Each of the three storage tanks holds 110 gal. (HX=heat exchanger, AFUE=annual fuel utilization efficiency).

\subsection{Monitoring Summary}

CARB has monitored the performance of the DHW system since May 2014. A more detailed description of the monitoring protocol and of the building overall is included in a previous report (Aldrich and Williamson 2014), but Figure 5 and Figure 6 show the basic monitoring configuration.

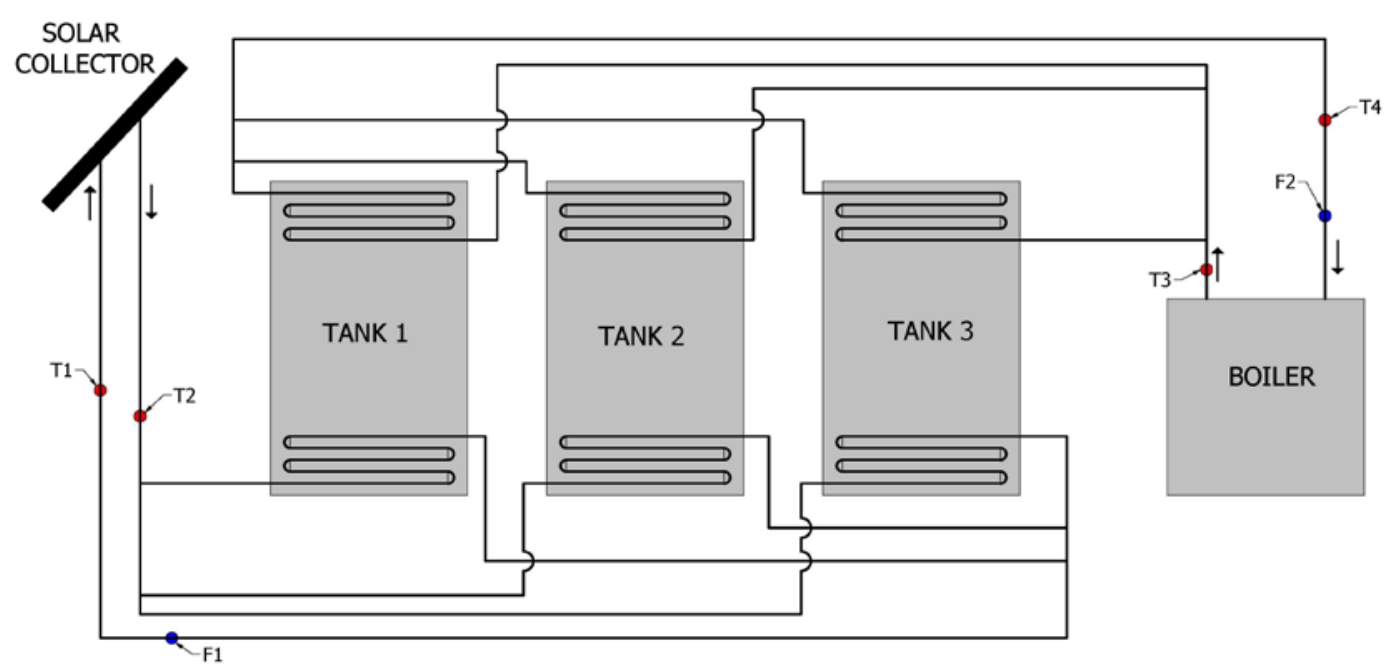

Figure 5. Schematic of sensor locations on the boiler and solar loops. $T$ indicates temperature sensor; $F$ indicates flow meter. 


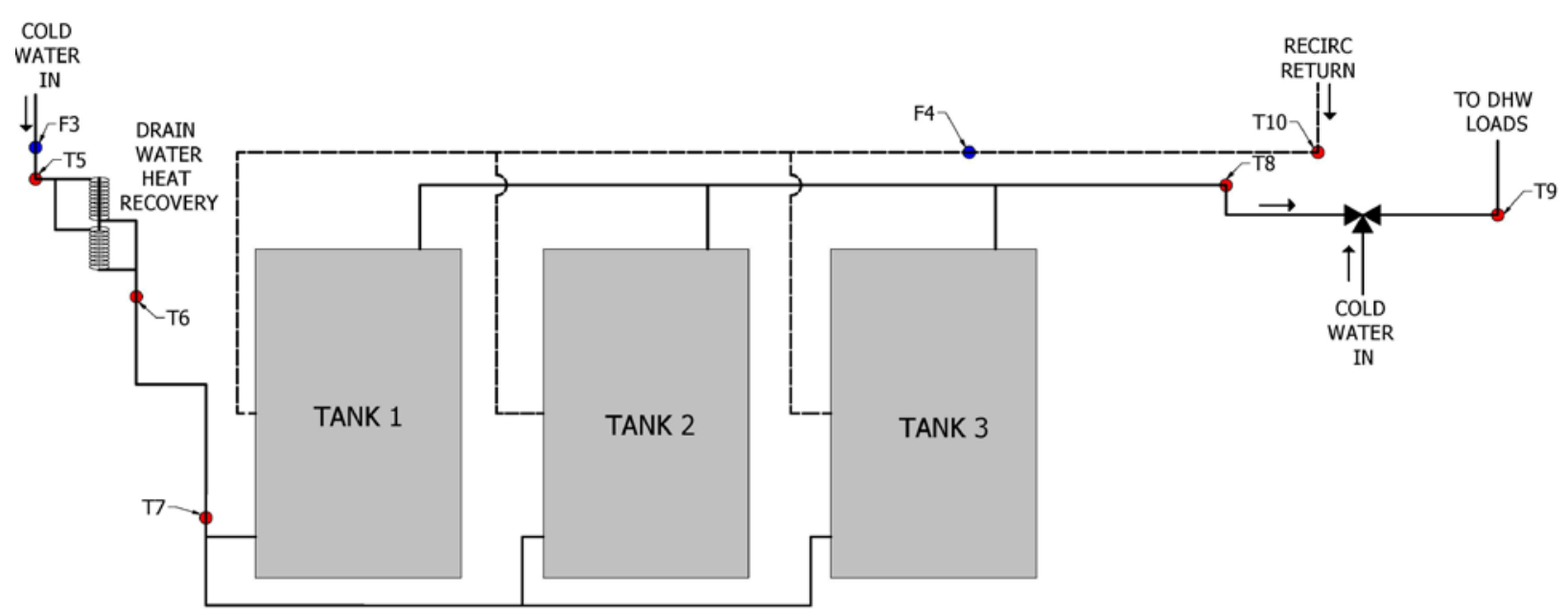

Figure 6. Schematic of sensor locations in potable water

Monitoring allowed CARB to calculate the following:

- Heat delivered to the storage tanks by solar

- Heat delivered to storage tanks by the boiler

- Domestic hot-water consumption

- Useful domestic water-heating energy

- Energy loss from the recirculation system.

Unfortunately, part way through the monitoring effort, the boiler-water flow meter failed. CARB was still able to monitor the other parts of the system, but standby losses could not be quantified and introduced some uncertainty.

Average hot-water consumption over the first 12 months monitored was $19 \mathrm{gal} / \mathrm{d}$ per apartment. This volume has varied little over the course of the first year. All 12 apartments were rented from the beginning of the monitoring effort, and there were 18 full-time residents in the entire building.

During afternoons in full sun, the solar system typically delivered $4-5 \mathrm{gal} / \mathrm{min}$ of glycol to the storage tanks at $130^{\circ} \mathrm{F}-160^{\circ} \mathrm{F}$. The typical glycol temperature rise from the solar collectors was $5^{\circ} \mathrm{F}-15^{\circ} \mathrm{F}$. In the period monitored to date, the solar-thermal system has provided an average of $102 \mathrm{kBtu} / \mathrm{d}$. Solar provided the large majority of water-heating needs during summer months and $48 \%$ of the annual water-heating load. The daily average water-heating loads (including breakdown of solar and boiler contributions) for each month are shown in Figure 7. Over the first 12 months that the building was occupied, the solar-thermal system offset about 450 therms of natural gas (saving $\$ 630$ at average gas rates of $\$ 1.40 /$ therm). 


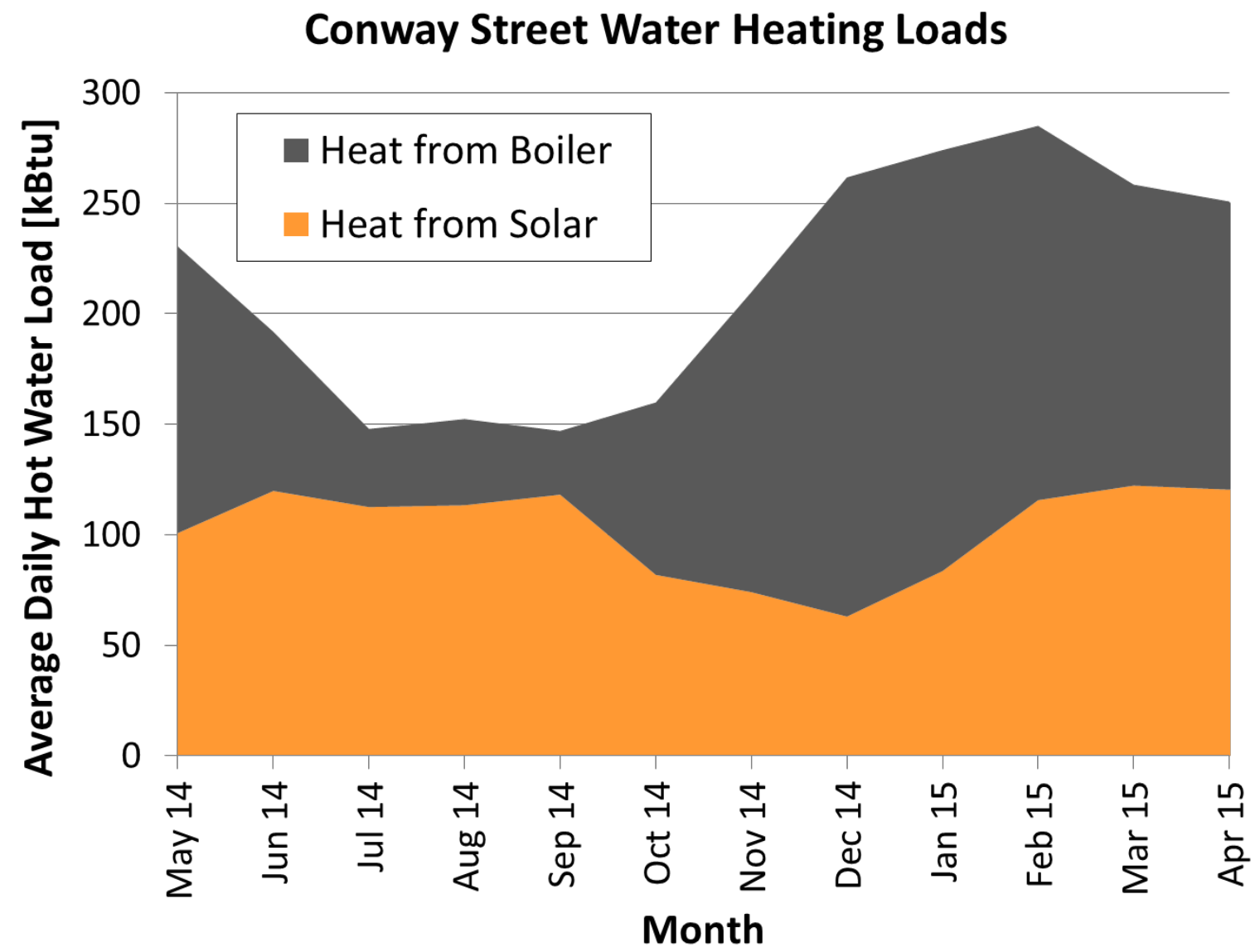

Figure 7. Daily average heat delivered for domestic hot water

As described in a previous report (Aldrich 2014), this building had a demand-controlled hotwater recirculation system that was installed improperly. The demand sensor itself was not installed, and the controller basically acted as a thermostat constantly keeping the recirculated water temperature at about $95^{\circ} \mathrm{F}$. During warmer months, this recirculation system was disabled completely. During colder months, however, there were a few occupant complaints about lukewarm water, and the malfunctioning recirculation system was reactivated. This additional recirculation load is the primary cause for the much higher winter loads shown in Figure 7. Data show that the recirculation system (with faulty controls) accounted for about $30 \%$ of the heat delivered to the hot water distribution system.

\subsection{Operations and Maintenance}

For the first 18 months of operation, the solar system has not required any expenditure for operation and maintenance. Future O\&M costs are difficult to predict, and the solar contractor did not provide any specific estimates. As discussed previously, maintenance costs related to solar systems are not well documented, and this can be a major gap in accurately assessing costeffectiveness of SDHW systems. 


\subsection{Cost-Effectiveness}

The total installed cost of the solar-thermal system for the twelve Conway Street apartments was about $\$ 31,000$. With 12 apartments, the cost per dwelling unit was just under $\$ 2,600$. Before construction, RETScreen modeling indicated that the solar-thermal system would provide about $50 \%$ of the total water-heating load assuming average consumption of $30 \mathrm{gal} / \mathrm{d}$ per apartment. At natural gas rates of $\$ 1.40$ per therm, this would result in savings of about $\$ 750$ per year for the entire building. With lower consumption (monitoring shows average use of $19 \mathrm{gal} / \mathrm{d}$ per apartment), a revised model showed reduced savings of $\$ 650$ per year. Once the adjusted waterconsumption values were included in the model, model results matched measured savings (\$630/year) quite closely. Without financial incentives, the initial cost of $\$ 31,000$ is difficult to justify with $\$ 650$ annual savings. The developer, however, was able to take advantage of the following substantial incentives:

- Massachusetts incentives based on the Solar Rating and Certification Corporation ratings of all installed collectors (MassCEC 2015)

- $30 \%$ federal tax credit

- Accelerated depreciation (SEIA 2015)

- Massachusetts utility incentives for efficient new construction.

Approximate impacts of these incentives are shown in Table 3. These incentive calculations are approximate because they make several assumptions (e.g., corporate tax rate, tax credits and deductions can be taken at the earliest opportunity, $4 \%$ discount rate). The incentives are substantial, and the developer was very clear that the incentives were crucial in the decision to install solar water heating.

Table 3. Summary of Approximate Solar-Thermal Costs and Incentives

\begin{tabular}{r|c}
\hline Gross Installed Cost & $\$(31,000)$ \\
Massachusetts Solar-Thermal Incentive & $\$ 8,664$ \\
$30 \%$ Federal Tax Credit & $\$ 6,701$ \\
Present Value of Depreciation Benefits (30\% Tax Rate) & $\$ 6,695$ \\
\hline Net Solar-Thermal Cost (Present Value) & $\$(8,940)$ \\
\hline Additional "Mass Save" Tier III Performance Incentive & $\$ 24,000$ \\
\hline
\end{tabular}

In addition to the state incentives for solar water heating, Massachusetts utilities had additional incentives for high-performance homes based on space-heating, cooling, and water-heating energy savings. The Conway Street apartments qualified for the highest level of incentives (Tier III) of $\$ 4,000$ per apartment. Tier III incentives would never have been achieved without the solar-thermal system; the excellent envelope systems and efficient heat pumps would have resulted in Tier II incentives of $\$ 2,000$ per apartment. Although not a direct solar-thermal incentive, the additional incentives of $\$ 24,000$ for overall building efficiency certainly justified the investment in solar water heating.

Olive Street Development is using lessons learned from the Conway Street apartments to plan for their next project: converting an empty school building in nearby Montague, MA, into 20 zero 
net energy apartments. Unlike the Conway Street project, this next project will have no access to natural gas. When compared to fuel oil, propane, or electric water heating, the savings from solar thermal will be considerably greater at current energy prices. Values in Table 4 use the Conway Street loads, solar fraction, and system costs to demonstrate approximate savings if other waterheating fuels were used. Even with more expensive fuels, the cost of a solar-thermal system still may be difficult to justify on an economic basis without financial incentives.

Table 4. Example Solar Savings with Other Water-Heating Fuels. Conway Street Loads and Costs Are Used.

\begin{tabular}{|c|c|c|c|c|c|}
\hline \multirow[b]{2}{*}{ Fuel } & \multirow{2}{*}{$\begin{array}{l}\text { Water-Heating } \\
\text { Fuel Efficiency }\end{array}$} & \multirow[b]{2}{*}{ Fuel $\operatorname{Cost}^{1}$} & \multicolumn{2}{|c|}{ Annual Solar Savings } & \multirow{2}{*}{$\begin{array}{c}\text { Simple Payback } \\
\text { (no incentives) }\end{array}$} \\
\hline & & & Fuel & Cost & \\
\hline Natural Gas & $85 \%$ & $\$ 1.40 /$ therm & 448 therms & $\$ 628$ & $49 \mathrm{yr}$ \\
\hline Propane & $85 \%$ & \$3.10/gal & 491 gal & $\$ 1,522$ & $20 \mathrm{yr}$ \\
\hline Electricity & $95 \%$ & $\$ 0.18 / \mathrm{kWh}$ & $11,754 \mathrm{kWh}$ & $\$ 2,116$ & $15 \mathrm{yr}$ \\
\hline Fuel Oil & $80 \%$ & $\$ 2.90 / \mathrm{gal}$ & 343 gal & $\$ 994$ & $31 \mathrm{yr}$ \\
\hline
\end{tabular}

\footnotetext{
${ }^{1}$ Prices from EIA for residential rates in Massachusetts.
} 


\section{Discussion}

As more homes move toward zero net energy consumption, developers are finding that addressing water-heating loads can be a challenge. Solar water heating has been used for decades, but - largely because of high costs - market penetration has remained modest in most parts of the country. In zero net energy buildings, however, first-cost is not the final consideration. In multifamily, zero-energy buildings especially, CARB believes that solar water heating may have a growing role for two key reasons:

- Compared to single-family buildings, economies of scale and consistent, diverse waterheating loads make solar water heating more cost-effective. One study showed that multifamily systems cost $28 \%$ less (per collector area) than single-family systems (Itron 2011).

- With very small space-conditioning loads, many zero-energy buildings are using airsource heat pumps to meet these loads. Using electric space heating has led some developers to forego fossil fuels entirely (along with the infrastructure costs and ongoing meter charges). Because heating water with electric resistance is quite costly, solar thermal can be much more appealing in all-electric buildings.

Although costs vary widely with application and region, solar-thermal systems are still relatively expensive; resources cited here show typical costs between $\$ 90$ and $\$ 160$ per square foot of collector area. Many federal and state incentives, however, can reduce these costs dramatically. In the Massachusetts case study described, a state incentive, the federal tax credit, and accelerated depreciation reduced the system cost from $\$ 31,000$ to about $\$ 9,000$ (present value). The SDHW system also helped qualify the building for higher-tier incentives for overall building efficiency; these additional incentives totaled $\$ 24,000$. For this project, incentives made the system quite compelling.

The system presented in the case study has worked well. During the first year monitored, the solar system has collected an average of $102 \mathrm{kBtu} / \mathrm{d}$ and provided $48 \%$ of the water-heating load. Over the first year, the system offset 450 therms of natural gas for a savings of $\$ 630$. If natural gas had not been available at this building, savings would have been higher: $60 \%$ higher for fuel oil, 140\% higher for propane, and 240\% higher for electric (at average Massachusetts energy rates). Solar-thermal systems have much higher savings with more expensive energy, but incentives are often still necessary to make systems cost-effective.

There are certainly challenges with solar water heating, and there are many multifamily applications where solar water heating may not be practical. In older buildings - especially very tall buildings - the difficulty of installing piping and limited space for collectors and storage can make installation of solar-thermal systems quite challenging. Other buildings may not have the necessary unshaded space for collectors.

Although several state programs have evaluation efforts under way, CARB was surprised at the lack of published performance data of SDHW on multifamily buildings. CARB believes that performance monitoring and evaluation are important to (1) assess how well measured performance matches predictions, (2) allow designers to optimize design or sizing, (3) assess 
long-term reliability, (4) document operations and maintenance costs over time, and (5) identify (and remedy) common performance problems. CARB believes more published performance evaluations and unbiased case studies can help developers and building owners make informed decisions about SDHW when designing zero net energy buildings. 


\section{Conclusions}

When compared to SDHW systems for single-family homes, solar-thermal systems in multifamily buildings can cost less (28\% less per unit area) and provide more useful energy because of the size and diversity of the DHW load. This is demonstrated both in the literature and in the case study evaluated here.

Even on multifamily buildings, however, SDHW systems remain relatively expensive. Installed costs typically range from $\$ 90-\$ 160 / \mathrm{ft}^{2}$ of collector area. System sizes vary widely, but most systems are between 3-30 $\mathrm{ft}^{2}$ per dwelling unit.

The most practical and cost-effective multifamily applications will include the following criteria:

- There is adequate, unshaded space for collectors.

- There is adequate space for thermal storage, preferably near the auxiliary water heater(s).

- Piping between collectors and storage is relatively short and can be installed with modest investment (this may favor new construction or gut rehabilitation over existing buildings).

- Auxiliary water-heating fuel is expensive (e.g., at current fuel prices, SDHW is often least cost-effective when compared to efficient natural gas water heating).

- There are state, utility, federal, or other financial incentives for SDHW.

The last bullet point is often the most critical. For the Massachusetts system examined here, financial incentives were the key to making the system viable. The considerable incentives made SDHW cost-effective at the Conway Street building even though efficient natural gas water heating was available.

There seem to be very few published performance evaluations or case studies of SDHW systems on multifamily buildings. More examples of long-term SDHW performance (including O\&M costs over time) can be very useful to developers and building owners in assessing the viability of solar water heating. 


\section{References}

Aldrich, R.; Vijayakumar, G. (2006). "Cost, Design, and Performance of Solar Hot Water in Cold-Climate Homes.” Proceedings Solar 2006. Boulder, CO: American Solar Energy Society, 2006.

http://apps1.eere.energy.gov/buildings/publications/pdfs/building_america/solar_hot_water_cold climate.pdf. Accessed April 2, 2015.

Aldrich, R.; Williamson, J. (2014). Conway Street Apartments: A Multifamily Deep Energy Retrofit. http://apps1.eere.energy.gov/buildings/publications/pdfs/building_america/conwaystapartments-multifamily-retrofit.pdf. Accessed April 1, 2015.

Baechler, M.; Gilbride, T.; Ruiz, K.; Steward, H.; Love, P. (2007). High-Performance Home Technologies: Solar Thermal \& Photovoltaic Systems. PNNL-16362. Richland, WA: Pacific Northwest National Laboratory. http://apps1.eere.energy.gov/buildings/publications/pdfs/building america/41085.pdf. Accessed May 13, 2014.

CA Utilities (2011). 2013 California Building Energy Efficiency Standards: Multifamily Central DHW and Solar Water Heating. California Utilities Statewide Codes and Standards Team. http://www.energy.ca.gov/title24/2013standards/prerulemaking/documents/current/Reports/Resi dential/Water_Heating/2013_CASE_R_MF_DHW_and_Solar_Water_Heating_Oct_2011.pdf. Accessed March 25, 2015.

CARB. (2010). Advanced Systems Research: Solar Thermal Systems at RDI's Wisdom Way Solar Village. Norwalk, CT: Consortium for Advanced Residential Buildings. Submitted to National Energy Technology Laboratory, December 9, 2010.

CEC. (2012). 2013 Title 24 Building Energy Efficiency Standards. Sacramento: California Energy Commission. CEC-400-2012-004-CMF.

CSI-Thermal. (2015). California Solar Initiative CSI-Thermal Program. Sacramento: State of California, California Energy Commission \& California Public Utilities Commission. http://www.gosolarcalifornia.ca.gov/solarwater/index.php. Accessed March 25, 2015.

DOE (2013). Solar Water Heater Basics. Washington, D.C.: U.S. Department of Energy. Accessed September 29, 2014: http://energy.gov/eere/energybasics/articles/solar-water-heaterbasics. Accessed April 1, 2015.

MassCEC. (2014). Commonwealth Solar Hot Water, Project Databases and Case Studies. Boston: Massachusetts Clean Energy Center. http://www.masscec.com/content/commonwealthsolar-hot-water-project-databases-and-case-studies. Accessed March 25, 2015.

EIA. (2009). Residential Energy Consumption Survey, Consumption and Expenditures by End Use. Washington, DC: U.S. Energy Information Administration. http://www.eia.gov/consumption/residential/data/2009/index.cfm?view=consumption\#end-use. Accessed April 1, 2015. 
EIA. (2012a). Annual Energy Review, Table 10.6. Washington, DC: U.S. Energy Information Administration. http://www.eia.gov/totalenergy/data/annual/showtext.cfm?t=ptb1006. Accessed April 1, 2015.

EIA. (2012b). Annual Energy Review, Table 10.7. Washington, DC: U.S. Energy Information Administration. http://www.eia.gov/totalenergy/data/annual/showtext.cfm?t=ptb1007. Accessed April 1, 2015.

EIA. (2015a). Electric Power Monthly. Washington, DC: U.S. Energy Information Administration. http://www.eia.gov/electricity/monthly/epm table_grapher.cfm?t=epmt_5_6_a. Accessed March 30, 2015.

EIA. (2015b). Natural Gas Prices. Washington, DC: U.S. Energy Information Administration. http://www.eia.gov/dnav/ng/ng pri sum a epg0 prs dmcf m.htm. Accessed March 30, 2015.

EIA. (2015c). Weekly Heating Oil and Propane Prices. Washington, DC: U.S. Energy Information Administration. http://www.eia.gov/dnav/pet/pet_pri_wfr_a_epd2f_prs_dpgal_w.htm. Accessed March 30, 2015.

Itron. (2011). California Center for Sustainable Energy Solar Water Heating Pilot Program: Final Evaluation Report. Davis, CA: Itron, Inc. http://www.cpuc.ca.gov/NR/rdonlyres/C1C7FD1005AA-493B-8CD0-F2C24DCA955A/0/CCSE SWHPP Rpt.pdf. Accessed March 30, 2015.

MassCEC. (2015). Commonwealth Solar Hot Water. Boston, MA: Massachusetts Clean Energy Center. http://www.masscec.com/programs/commonwealth-solar-hot-water. Accessed April 2, 2015.

Mehalic, B. (2010). “Drainback Solar Hot Water Systems.” Home Power Magazine. www.homepower.com/articles/solar-water-heating/domestic-hot-water/drainback-solar-hotwater-systems. Accessed February 17, 2016.

Ritschard, R.; McAllister, A. (1992). Persistence of Savings in Multifamily Public Housing. Proceedings of the 1992 ACEE Summer Study on Energy Efficiency in Buildings. Washington, DC: American Council for an Energy Efficient Economy. http://aceee.org/files/proceedings/1992/data/papers/SS92 Panel4 Paper23.pdf. Accessed April $1,2015$.

Rittlemann, W. (2004). Field Investigation of 18 Solar-Assisted Domestic Hot Water Systems With Integral Collector Storage. Proceedings of the 2004 ACEEE Summer Study on Energy Efficiency in Buildings. Washington, DC: American Council for an Energy Efficient Economy. http://aceee.org/files/proceedings/2004/data/papers/SS04_Panel1_Paper24.pdf. Accessed April $2,2015$.

SEIA. (2015). Depreciation of Solar Energy Property in MACRS. Washington, DC: Solar Energy Industries Association. http://www.seia.org/policy/finance-tax/depreciation-solar-energyproperty-macrs. Accessed April 1, 2015. 
Springer, D.; Seitzler, M.; Backman, C. (2014). Addressing Multifamily Piping Losses with Solar Hot Water. Davis, CA: Alliance for Residential Building Innovation. 

Renewable Energy 